\title{
PUBLIC AND PRIVATE INTERNATIONAL LAW: GERMAN VIEWS ON GLOBAL ISSUES
}

\author{
RALF MICHAELS
}

\section{A. The Publicisation of Private International Law?}

The relationship between public and private international law, the issue of the excellent book under review, ${ }^{1}$ has often been addressed. But the question is ever new because it is asked under ever-changing circumstances. First, circumstances differ between countries. In the United States, there has long been a tendency towards unifying public international law and (international) choice of law (which is, tellingly, dealt with in the Restatement for Foreign Relations). ${ }^{2}$ In England, the separation of private and public international law has remained much more stable, at least until recently. ${ }^{3}$ Second, such circumstances change over time, ${ }^{4}$ between, say, the 19 th century when a separation seemed appropriate $^{5}$ and the 20th century when some jurisdictions experienced a greater influence of public on private international law. ${ }^{6}$ The current age of globalisation seems to put all such distinctions into question. ${ }^{7}$ Recently, there seems to be a

* Many thanks for very valuable advice to Karen Knop, University of Toronto, and for splendid research to Catherine Gibson, JD/LLM (Duke) 2008.

$1 \quad \mathrm{~S}$ Leible and M Ruffert (eds), Völkerrecht und IPR (Jena, Jenaer Wissenschaftliche Verlagsgesellschaft, 2006).

2 Restatement of the Law (3d), The Foreign Relations Law of the United States (1987), §§ 402-16. Mathias Reimann has asked that a potential new restatement of conflict of laws account for international choice of law: "A New Restatement for the International Age" (2000) 75 Indiana Law Fournal 575. See also Academic Workshop: Should We Continue to Distinguish between Public and Private Law? (1985) 79 ASIL Proceedings 352

3 A Mills, "The Private History of International Law" (2006) 55 International and Comparative Law Quarterly 1.

4 A Nussbaum, "The Rise and Decline of the Law-of-Nations Doctrine in the Conflict of Laws" (1942) 52 Columbia Law Review 189.

5 Eg R Phillimore, Commentaries upon International Law (1854) 54; J Westlake, A Treatise on Private International Law of Conflict of Laws (1859) 18. More recently for strict distinction, see R Jennings and A Watts (eds), Oppenheim's International Law (London, Longman, 9th edn, 1996), 6-7; MN Shaw, International Law (Cambridge University Press, 5th edn, 2003).

$6 \quad$ PM Brown, "Private versus Public International Law" (1942) 36 American Fournal of International Law 448; JR Stevenson, "The Relationship of Private International Law to Public International Law" (1952) 52 Columbia Law Review 561, 564; G Schwarzenberger, A Manual of International Law (London, Institute of World Affairs, 5th edn, 1967) 4; JR Paul, The Isolation of Private International Law (1989) 7 Wisconsin International Law Fournal 149.

7 Literature on this has no boundaries. See the references in R Michaels, "Welche Globalisierung für das Recht? Welches Recht für die Globalisierung?” (2005) 69 Rabelsz 525; R Michaels and 
tendency towards merging the two fields - either under an expanded understanding of public international law (sometimes under the name of transnational law or process), ${ }^{8}$ or as a publicisation of private international law. ${ }^{9}$ At least, so it is argued, the relevance of public international law and the international order for private international law needs to be highlighted more. ${ }^{10}$

This alleged tendency towards a merger, and towards prioritising public over private international law, emerges mostly from an expansion of public international law. Traditional public international law (at least since the 19th century) dealt with relations between countries and left the role of private actors to private international law. Now that multinational corporations and individuals have come into the focus of public international law, this distinction has become less clear. ${ }^{11}$ Traditional public international law focused very much on international politics and left economic matters largely to private international law; today, international economic law has become a central feature of public international law. Traditional public international law was strictly international and therefore distinct from domestic private international law. Today, public international law is becoming domesticated, ${ }^{12}$ and several different domestic variants of public international law emerge, as diverging views between the US Supreme Court and the German Constitutional Court regarding the impact of the Vienna Convention on Consular Relations show quite clearly. ${ }^{13}$ Traditional

N Jansen, "Private Law Beyond the State? Europeanization, Globalization, Privatization" (2006) 54 American Fournal of Comparative Law 843; N Jansen and R Michaels, "Private Law and the State - Comparative Perceptions and Historical Dimensions" (2007) 71 Rabelsz 345, all with extensive further references. More recently, see E Leibfried et al (eds), Transforming the Golden-Age Nation State (Basingstoke, Palgrave Macmillan, 2008).

$8 \quad$ Eg PC Jessup, Transnational Law (New Haven, Yale University Press, 1956); Paul, supra n 6, 158-9; HH Koh, "Transnational Legal Process" (1996) 75 Nebraska Law Review 181; for a summary and evaluation of the debate, see P Zumbansen, "Transnational Law", in J Smits (ed), Elgar Encyclopedia of Comparative Law (Cheltenham, Edward Elgar, 2006), 738.

9 H Muir Watt, "Droit public et droit privé dans les rapports internationaux (Vers la publicisation des conflits de lois?)" (1997) 41 Archives de philosophie du droit - le privé et le public 207; PS Berman, "From International Law to Law and Globalization" (2005) 43 Columbia Journal of Transnational Law 485 518-23.

10 Mills, supra $\mathrm{n} 3$.

11 Eg A Clapham, Human Rights Obligations of Non-State Actors (Oxford University Press, 2006); O Dörr, "Privatisierung' des Völkerrechts" (2005) 60 Juristenzeitung 905; T Meron, The Humanization of International Law (Leiden, Nijhoff, 2006).

12 A-M Slaughter and W Burke-White, "The Future of International Law is Domestic (or The European Way of Law)" (2006) 47 Harvard International Law fournal 327.

13 Sanchez-Llamas v Oregon, 548 US 331 (US S Ct 2006); Bundesverfassungsgericht (BVerfG German Federal Constitutional Court), 19 Sep 2006, 2 BvR 2115/01, International Law in Domestic Courts (ILDC) 668 (DE 2006). For comparison, see J Gogolin, "Avena and SanchezLlamas Come to Germany - The German Constitutional Court Upholds Rights under the Vienna Convention on Consular Relations" (2007) 8 German Law Fournal 261, http://www. germanlawjournal.com/article.php?id=805; KF Gräditz, "German Federal Constitutional Court: Decision on Failure to Provide Consular Notification" (2007) 101 American fournal of International Law 627; C Hoppe, "Implementation of LaGrand and Avena in Germany and the United States: Exploring a Transatlantic Divide in Search of a Uniform Interpretation of 
public international law relied to a large extent on open concepts and on subtle and case-specific balancing of interests instead of formal and technical rules. Today's public international law rests more and more on technical language traditionally reserved to private international law.

Yet even if public international law is expanding, this expansion comes at the expense not of private international law but of the specific public character of public international law. ${ }^{14}$ Privatisation and the growing importance of private actors present a challenge to public international law. By contrast, we should expect a boost for private international law.

This makes it attractive to look to a country in which the distinction between private and public international law is still quite intact: Germany. Although almost all German academics today have been exposed to foreign experience and many have pursued higher-level academic studies in other countries (most frequently the United States or England), theirs remains, mostly, a specifically German perspective. This perspective is especially interesting because, as Klaus Schurig makes clear in this book, ${ }^{15}$ the distinction between private and public law, considered passé in many other systems, is still central to German legal thought. ${ }^{16}$ That distinction exists not only in domestic law, but also in international law. Public and private international law are strictly separate disciplines; the last German professor officially entitled to teach both and having published widely in both (at least according to the introduction to the book under review), ${ }^{17}$ Wilhelm Wengler (whose estate subsidised the conference leading to the book under review), passed away more than ten years ago. ${ }^{18}$ Public and private voices are brought together rarely, except under the aegis of the German Society of International Law, ${ }^{19}$ which produces annually a book in which public and private international lawyers address the same issues from the perspectives of their respective disciplines. ${ }^{20}$

Consular Rights" (2007) 18 European Fournal of International Law 317. The latest US Supreme Court decision on these questions is Medellin v Texas (25 Mar 2008), (2008) 76 United States Law Week 4143.

14 RG Steinhardt, "The Privatization of Public Law" (1991) 25 George Washington Fournal of International Law and Economics 523, 544. B Kingsbury, "The Problem of the Public in International Law" (NYU Law School, working paper, 2005).

15 K Schurig, "Völkerrecht und IPR: Methodische Verschleifung oder strukturierte Interaktion?", in Leible and Ruffert, supra n 1, 55, 56-7.

16 See Jansen and Michaels, supra $\mathrm{n} 7$.

17 Burkhard Hess at Tübingen reportedly also holds a venia in public and private international law.

18 On Wengler, see S Leible and M Ruffert, "Einführung", in Leible and Ruffert, supra n 1, 17, 19-20 with further references in n 14; for a brief obituary, see also C Dominicé (Secretary General's report), (1996) 66 II Annuaire de l'Institut de Droit International 52.

19 "Deutsche Gesellschaft für Völkerrecht", not to be confused with the "Deutsche Vereinigung für Internationales Recht", the German branch of the International Law Association (ILA).

20 Berichte der Deutschen Gesellschaft für Völkerrecht; for a list, see http://www.dgvr.de/ berichte.pdf. 
This excellent new collection of essays deserves attention, because it brings this specifically German dual perspective to the issues at stake. Edited by a private international lawyer (Stefan Leible) and a public international lawyer (Matthias Ruffert), it assembles a great portion of the leading German authorities on public and private international law, respectively. The editors wisely assigned several topics to one private and one public international law expert. Comparison of the respective disciplinary views reveals stark differences, ${ }^{21}$ the combination shows that any assumed amalgam of public and private international law would internally still be quite heterogeneous. At the same time, because all authors are German academics, the book provides us with specifically German views.

The book combines 13 essays on various topics, and not all of them concern specifically private or public international law. Instead of addressing them in the order of the book, this review will therefore try to place the German answers within more general debates on three issues. The first issue concerns the degree to which public international law determines private international law rules between states. The second issue is whether the role of the individual, as expressed especially in human rights, has an impact on private international law. The third issue, finally, concerns the private/public mix of the global economy. Are private and public international law merging within international economic law? How is the distinction between these two legal areas affected by the increasing role of states as market participants? On the basis of these three issues, we can address the general question: is private international law being publicised, or are we observing a return of the private?

\section{B. Public International Law Duties towards Foreign Countries}

To what extent does public international law determine the content of private international law? In the United States, although choice of law for international conflicts is part of the Restatement of Foreign Relations Law, the relevant rules restate US practice on choice of law rather than public international law. In other countries, there is mostly agreement that public international law places minimal, if any, restraints on private international law. In this volume, Karl Heinz Ziegler treats the history, Heinz-Peter Mansel the current state of views. They show that, at least from a German perspective, the role of traditional public international law in this regard is very limited; but rules focused on individuals, especially human rights rules, may well become more important.

21 Similarly H-P Mansel, "Staatlichkeit des Internationalen Privatrechts und Völkerrecht", in Leible and Ruffert, supra n 1, 89, 91 


\section{Customary International Law}

Attempts to develop a public international law of allocation of jurisdiction, including jurisdiction to prescribe, were popular in Germany around the turn of the 19th century (Zitelmann, Frankenstein) and have more recently been revived by a public international lawyer (Albert Bleckmann). ${ }^{22}$ These attempts have been unsuccessful, as Hans Peter Mansel shows in a very rich study of the relationship between a domestic understanding of choice of law and public international law. ${ }^{23}$ First, there is no common state practice except for the most unproblematic cases. ${ }^{24}$ Violations of accepted choice-of-law principles do not yield diplomatic protests; at best, the resulting decisions are denied recognition. ${ }^{25}$ Any attempt to be more specific must therefore be axiomatic, as was indeed the case for Zitelmann's theory. Second, such an idea can rarely lead to rules of the necessary specificity. ${ }^{26}$ At best, it results in the vacuous finding that each state must have a regime to deal with private international law questions. This finding is fatal also to the idea of "dédoublement", presented especially by Scelle, that domestic rules on private international law are at heart international law norms, mirrored in domestic law that thereby becomes an executor of public international law. ${ }^{27}$

The most important restraint arising from customary international law is the genuine link requirement, established by the International Court of Justice to justify the exercise of jurisdiction. ${ }^{28}$ Walter Wheeler Cook showed as early as 1942 that such a criterion rarely leads to meaningful restraints. ${ }^{29}$ Alexander Makarov had reached a similar conclusion three years earlier. ${ }^{30}$ Mansel, in a very careful and generous analysis, comes largely to the same result, at least for areas of traditional private law. The criterion is both too broad and too vague to yield

22 E Zitelmann, Internationales Privatrecht (3 vols, Munich, Duncker \& Humblot, 1897-1912); E Frankenstein, Internationales Privatrecht (Grenzrecht) (4 vols, Berlin-Grunewald, Dr Walther Rothschild, 1926-35): A Bleckmann, Die völkerrechtlichen Grundlagen des internationalen Kollisionsrechts (Cologne, Heymanns, 1992). For a French reception, see $\mathrm{P}$ de Vareilles-Sommières, La Compétence de l'Etat en matière de droit privé (Paris, LGDJ, 1997).

23 Mansel, supra n 21, 89.

24 Mansel, supra n 21, 111-14; Schurig, supra n 15, 60-1; similarly B Audit, Droit International Privé (Paris, Economica, 4th edn, 2006), 30-1; C von Bar and P Mankowski, Internationales Privatrecht, vol 1 (Munich, Beck, 2nd edn, 2003), § 3 nos 8-13.

25 WE Beckett, "What Is Private International Law?" (1926) 7 British Yearbook of International Law 73.

26 Mansel supra n 21, 97-103.

27 See A Cassese, 'Remarks on Scelle's Theory of 'Role Splitting' (dédoublement fonctionnel) in International Law" (1990) 1 European Fournal of International Law 210.

28 Nottebohm case (Liechtenstein v Guatemala), 1955 ICJ Rep 4; see already the case of the SS Lotus (France v Turkey), 1927 PCIJ (Ser A) No 10.

29 W Wheeler Cook, The Logical and Legal Bases of the Conflict of Law (Cambridge, MA, Harvard University Press, 1942), 71-8, discussing limited practical effect of the Lotus decision of the ICJ.

30 A Makarov, "Völkerrecht und Internationales Privatrecht", in Mélanges Streit, vol 1 (Athens 1939), 535, 548-9 and passim. Cf E Jayme, Internationales Privatrecht und Völkerrecht (Heidelberg, Müller, 2003), 18-19. 
private international law rules. ${ }^{31}$ At best, the criterion results in a multitude of countries having jurisdiction; it says nothing about the role of private international law in deciding which of these countries' laws should apply. It is hard to imagine a rule of private international law using a connecting factor more ephemeral than what is required by public international law.

\section{Comity}

The more prominent foundation for the obligation to apply foreign laws has always been comity. ${ }^{32}$ Although Dicey famously called it "a singular specimen of confusion of thought produced by laxity of language", 33 it still plays an important role in Anglo-American conflicts thinking. The US Supreme Court uses it frequently as its basis for international cases - although comity, enigmatically defined in a leading decision as "neither a matter of absolute obligation, on the one hand, nor of mere courtesy and good will, upon the other", ${ }^{34}$ provides hardly any clear guidelines. ${ }^{35}$ In England, where choice of law is now mostly based on specific rules, comity plays a limited role as a restriction especially for service out of the jurisdiction, for anti-suit injunctions and for Mareva injunctions. ${ }^{36}$

In Germany, a public concept of comity plays hardly any role today, except perhaps to express a generally friendly attitude towards foreign law. ${ }^{37}$ Karl-Heinz Ziegler, in his contribution as a historian of public international law, pleads for a greater role for comity in private international law. ${ }^{38}$ However, when he suggests viewing Savigny's use of the concept of comity in relation to views on public

31 Mansel, supra n 21, 117-28 cites to two decisions by the German Federal Court of Justice (Bundesgerichtshof), questioning the genuine link between a state and a corporation incorporated under that state's law. Denial of such a link could not be based on international law.

32 Eg H Yntema, "The Comity Doctrine" (1966) 65 Michigan Law Review 9 with a historical "Foreword" by K Nadelmann, ibid 1; J Paul, "Comity in International Law" (1991) 32 Harvard International Law Fournal 1; J Paul, "The Transformation of International Comity" (2008) 71/3 Law and Contemporary Problems (forthcoming).

33 AV Dicey, The Conflict of Laws (1st edn, 1896), 10, quoted with approval by HF Goodrich, Handbook of the Conflict of Lawes (St Paul, MN, West Publishing, 3rd edn, 1949), 11-12.

34 Hilton v Guyot, 159 US 113, 163-4 (US S Ct 1895).

35 See, most recently, L Collins, "The United States Supreme Court and the Principles of Comity: Evidence in Transnational Litigation" (2006) 8 Kearbook of Private International Law 53.

36 Derby \& Co Ltd v Weldon (Nos 3 and 4) [1990] Ch 65, 82 (CA); Crédit Suisse Fides Trust SA v Cuoghi [1998] QB 818, 827 (CA) per Millett LJ. See, more generally, L Collins, "Comity in Modern Private International Law", in J Fawcett (ed), Reform and Development of Private International Law: Essays in Honour of Sir Peter North (Oxford University Press, 2002), 89.

37 See G Kegel and K Schurig, Internationales Privatrecht (Munich, Beck, 9th edn, 2004), 185; KH Ziegler, "Völkerrechtliche Verpflichtung zur Anwendung oder nur 'freundliche Beachtung' fremden Rechts? Die comitas-Lehre heute (Betrachtungen eines Rechtshistorikers)", in Leible and Ruffert, supra n 1, 43, 54); Schurig, supra n 15, 60.

38 Ziegler, ibid.

39 Ziegler, ibid, 46-7 hints at a possible connection between Savigny's private international law and the public international law of his time. For reasons expressed in the text I would not expect this to be fruitful.

40 See G Kegel, "Story and Savigny" (1989) 37 American fournal of Comparative Law 39. 
international law of the time, ${ }^{39}$ he underestimates the fundamental shift in the nature of the concept as espoused by Joseph Story and by Friedrich Carl von Savigny. ${ }^{40}$ Story had defined private international law as a subdiscipline of international law, ${ }^{41}$ and connections to public international law and/or federalism were always important in his work. This understanding of comity as concerning relations between governments established private international law as a discipline of conflicts between different governments, and thereby lent itself nicely to 20th-century conceptions of conflict of laws as conflicts of governmental interests, at heart very much a public law conception of conflict of laws. Savigny, by contrast, came not from international law but from private law. His treatise on private international law was written merely as the eighth and final volume of his magnum opus on Roman (private) law. ${ }^{42}$ The questions to which Savigny responds are questions of private law, especially of the reach (over space and time) of private law rules. Because private law is, in Savigny's conception, distinct from the will of any legislator, private international law has little to do with the mutual respect between sovereigns. Instead, comity signifies, for Savigny, a "recognized community of different nations". ${ }^{43}$ To quote Kegel, "The "völkerrechtliche Gemeinschaft' was not a community of international law, but a legal community of peoples. ${ }^{24}$

This led to a fundamental difference in conception, not only of comity but also of private international law. The end of private international law for Story is a situation of mutual respect and harmony between states; for Savigny it is "an international common law of nations", a "universal customary law". ${ }^{45}$ Story expects agreement between states over allocation of lawmaking capacity; Savigny expects a trend towards substantive harmonisation of laws. Story maintains the international law character of private international law; with Savigny, for the first time, private international law is truly privatised. ${ }^{46}$ This distinction of concepts is thus of crucial importance. Many of the differences between US and, especially, continental private international law can be explained by this decisive move in the 19th century. More importantly, in an age of decreasing relevance of the state and increasing attention to private matters, Savigny's civil society

41 J Story, Commentaries on the Conflict of Lawes (3rd edn, 1846), 13.

42 On the origins of this volume, see F Sturm, "Savigny und das internationale Privatrecht seiner Zeit" (1979) 8 Ius commune 92.

43 F von Savigny, A Treatise on the Conflict of Laws, and the Limits of their Operation in Respect of Place and Time (W Guthrie trans, 1880), 45.

44 Kegel, supra n 40, 59; see already M Gutzwiller, Der Einfluss Savignys auf die Entwicklung des Internationalprivatrechts (Freiburg [Switzerland], Universitätsverlag Gschwend, Tschopp \& Co, 1923), $43-4$.

45 Savigny, supra n $43,70$.

46 Kegel, supra n 40, 58-9.

47 For limits to Savigny as a model for globalised conflict of laws, see R Michaels, "Globalising Savigny? The State in Savigny's Private International Law and the Challenge from Europeanization and Globalization", in M Stolleis and W Streeck (eds), Dezentralisierung. Aktuelle Fragen politischer und rechtlicher Steuerung im Kontext der Globalisierung (Baden-Baden: Nomos, 2007), 119. 
concept of comitas gentium may well win the day over the public international law conception prevalent in Joseph Story's work. ${ }^{47}$

\section{Choice-of-Law Treaties}

With the limited role of general international law and the unclear character of comity as a public concept, the burden of choice of law could be thought to rest on treaties, addressed briefly by Heinz-Peter Mansel. ${ }^{48}$ (Jürgen Basedow's contribution on treaties concerns mostly substantive private law, not private international law. ${ }^{49}$ ) Beginning with Mancini's conception of private international law as based on a world of sovereign nations and the adoption of this idea by the International Law Institute in $1874 / 75,{ }^{50}$ treaties had been viewed as the best instrument to overcome undesired differences between domestic rules on private international law. ${ }^{51}$ Scholars proposed them as a means to achieve unity, ${ }^{52}$ the Hague Conference on Private International Law was established to further the development of such treaties. Underlying such hopes was the assumption that private international law unification must and can be mediated via states as treaty parties. This hope has not been fulfilled. What Basedow says in this book with regard to the unification of substantive private law ${ }^{53}$ applies equally well to choice of law: general public international law instruments, including in particular the Vienna Convention on the Law of Treaties, are inadequate for private international law. Unified choice-of-law rules do not merely place obligations on states, they unify the law itself. As a consequence, the nature of private international law lends itself more to uniform legislation than to international conventions as a method of unification, ${ }^{54}$ to private-law-like codification

48 Mansel, supra n 21, 103-11.

49 J Basedow, "Das Konventionsprivatrecht und das Völkerrecht der Staatsverträge", ibid, 153.

50 See E Jayme, "Völkerrecht und Internationales Privatrecht - Eine entwicklungsgeschichtliche Betrachtung", in Leible and Ruffert, supra n 1, 23, 24-6; the resolution of the Institute is ibid, 39-40; see also, briefly, Basedow, supra n 49, 156-7.

51 See KH Nadelmann, "Multilateral Conventions in the Conflicts Field: An Historical Sketch" (1972) 19 Netherlands International Law Review 107.

52 PS Mancini, "De l'utilité de rendre obligatoires pour tous les Etats, sous la forme de plusieurs traités internationaux, un certain nombre de règles générales du Droit international prié pour assurer la decision uniforme des conflits entre les différentes égislations civiles et criminelles" Clunet 1 (1874), 221-39, 285-304.

53 Supran 49.

54 K Nadelmann, "Uniform Legislation versus International Conventions as a Method of Unification of Private International Law", in K Nadelmann, Conflict of Laws: International and Interstate: Selected Essays (The Hague, Nijhoff 1972), 87.

55 See K Nadelmann, "Mancini’s Nationality Rule and Non-Unified Legal Systems" (1969) 17 American Fournal of Comparative Law 418, 422-3. A prominent proponent of codification was none other than David Dudley Field, famous for his promotion of codification of domestic law in New York.

56 See R Michaels, "The European Choice-of-Law Revolution" 82 Tulane Law Review II.A (forthcoming).

57 J Basedow, "Was wird aus der Haager Konferenz für Internationales Privtrecht?" in T Rauscher and H-P Mansel (eds), Festschrift für Werner Lorenz zum 80. Geburtstag (München, Sellier, 2001), 463; M Traest, "Development of a European Private International Law and the Hague Conference" (2003) 5 Kearbook of Private International Law 223. 
(as had been proposed prior to Mancini). ${ }^{55}$ In Europe, uniform legislation is replacing the traditional focus on Conventions; ${ }^{56}$ this is one of several reasons for the crisis of the Hague Conference. ${ }^{57}$ A recent proposal to harmonise global private international law through the development of a restatement of general principles, similar in nature to the UNIDROIT Principles of International and Commercial Contracts, ${ }^{58}$ displays a view of private international law as distinct from public international law and treaties among sovereigns.

\section{International Trade Law}

Arguably, the biggest potential for public international law restraints on private international law lies not in general public international law, but in trade law. This is so under two aspects. A first aspect - the duty to treat different countries alike or to grant most favoured-nation status - is addressed in this volume by Peter Mankowski. ${ }^{59}$ Most-favoured-nation clauses are not specific to the World Trade Organization (WTO) and the General Agreement on Tariffs and Trade, they exist also in treaties of friendship, commerce and navigation. Their immediate target is public regulation, but they may well be applicable to private international law too. Their effect may be that specific rules of inter-European private international law, based on the specific requirements of the Common Market, must be extended to third countries. This is not idle speculation. When the European Court of Justice decided, in its Centros trilogy of cases, that Member States like Germany had to recognise corporations even when these were established under a law other than that of their effective seat, it had in mind only the protection of Member State corporations. However, the German Federal Court of Justice decided that the same degree of recognition is owed to US (especially Delaware) corporations under the US-German Friendship Treaty. ${ }^{60}$

A second aspect concerns the question whether choice-of-law rules can be viewed as discriminatory, directly or indirectly. These questions have become prominent with regard to requirements of $\mathrm{EU}$ law, ${ }^{61}$ which is not covered here because it is not viewed strictly as public international law. But such questions might also arise under WTO law. For example, it has been argued that WTO law

58 H Kronke, "Most Significant Relationship, Governmental Interests, Cultural Identity, Integration: 'Rules' at Will and the Case for Principles of Conflict of Laws" (2004) 9 Uniform Law Review 467.

59 P Mankowski, "Völkerrechtliche Meistbegünstigung und europäisches IPR/IZVR" in Leible and Ruffert, supra n 1, 235.

60 Bundesgerichtshof, 29 Jan 2003 VIII ZR 155/02, [2003] Neue Furistiche Wochenschrift 1607; JC Dammann, "Amerikanische Gesellschaften mit Sitz in Deutschland. Zugleich eine Anmerkung zu BGH 29.1.2003 - VIII ZR 155/02” (2004) 65 RabelsZ 1. Mankowski, supra n 59, 262 argues that the result followed already from a choice of law rule in the US-German Treaty.

61 See J Meeusen, "Instrumentalisation of Private International Law in the European Union: Towards a European Conflicts Revolution?” (2007) 9 European Fournal of Migration and Law 287, $291 \mathrm{ss}$; Michaels, supra n 56, II.3.b. 
requires a lex loci delicti rule to ensure that no discrimination between local and foreign market participants ensues. ${ }^{62}$ The ultimate consequence of such arguments would be that the relevant market would provide the only permissible connecting factor for rules of private international law. ${ }^{63}$ Although such extreme developments seem unlikely at this stage, their consideration shows how the centre of the debate has shifted. The development in globalisation away from state sovereignty and towards markets is matched by the relevance of public international law to private international law. State sovereignty, classical public international law, has lost its importance. By contrast, market-related rules of public international law have a potential impact on private international law that is so far underappreciated.

\section{G. Public International Law Duty towards Individuals}

The move from states to markets is also a move from states to individuals and their rights. Public international law rules on rights can play a role in private international law in two conceptions: the private law conception of acquired or vested rights, and the broader conception of human rights. The first one has long been more prominent; the second one is gaining ground.

\section{Acquired Rights}

Public international law has historically required countries to recognise rights, especially property rights, acquired under foreign law. For some time, such an idea was translated directly into private international law. The vested rights theory, prominent for some time under legal systems as different as those of France, England and the United States, provided the basis for private international law: courts were required to enforce rights acquired under a foreign law. That theory is dead - "brutally murdered" in the United States, ${ }^{64}$ gently edited out of later editions from the leading textbook in England. ${ }^{65}$ By then the theory

62 J Goldsmith and AO Sykes, "Lex Loci Delictus and Global Economic Welfare: Spinozzi v ITT Sheraton Corp" (2007) 120 Harvard Law Review 1137, 1144-5. More generally on the potential impact of WTO law on private international law, see W-H Roth, "Welthandelsordnung und IPR" (2003) 40 Berichte der deutschen Gesellschaft für Völkerrecht 331. For a conceptualisation of the WTO as a conflict-of-laws system, see C Joerge, "Constitutionalism in Postnational Constellations: Contrasting Social Regulation in the EU and in the WTO", in C Joerges and E-U Petersmann (eds), Constitutionalism, Multilevel Trade Governance and Social Regulation (Oxford, Hart Publishing, 2006), 491.

63 For the market as relevant connecting factor, see D Martiny, "Die Anknüpfung an den Markt", in Festschrift für Ulrich Drobnig zum siebzigsten. Geburtstag (Tübingen, Mohr Siebeck, 1998), 389.

64 N de Belleville Katzenbach, "Conflicts on an Unruly Horse: Reciprocal Claims and Tolerances in Interstate and International Law" (1956) 65 Yale Law fournal 1087, 1087.

65 See JC Morris (gen ed), Dicey's Conflict of Laws (London, Stevens \& Sons and Sweet \& Maxwell, 6th edn, 1949) LXV; JC Morris (gen ed), Dicey's Conflict of Laws (London, Stevens \& Sons, 7th edn, 1958), 9. 
had long been rejected in Germany by Wächter and Savigny. ${ }^{66}$ As a consequence, it never gained ground and is mentioned in this book merely in passing. ${ }^{67}$

Narrowly understood, the theory no longer plays a role. However, as I have argued elsewhere, it has been reborn in the European Union in the form of a country-of-origin principle. ${ }^{68}$ The idea behind this principle is that a market participant who complies with the rules of its home state thereby acquires, metaphorically speaking, a privilege (a "vested right") that it can ask to be enforced anywhere else where it does business. This is relevant in the European Union (although, for the moment, a country-of-origin principle has been deleted from the important services directive.) A European country-of-origin principle may have to be extended to third-country domiciliaries as a consequence of most-favoured-nation clauses, as Mankowski shows. ${ }^{69}$ Under general public international law, a similar concept does not exist. A country-of-origin rule is part, however, of certain specific conventions like the Berne Convention. Rules of origin under WTO law play a different role; they define the country of origin, but they do not defer to that country's laws.

\section{Human Rights}

If the role of acquired rights in this area is thus limited, the role of innate rights may be huge. This at least is the fascinating thesis of Erik Jayme. Jayme, in his contribution on the history of public and private international law, avoids almost all reference to the usual themes of comity. Instead, starting with Kant, ${ }^{70}$ he views the most important link between public and private international law in human rights as a basis of specifically private international law. ${ }^{71}$ Most importantly, human rights require states to recognise foreign citizens as humans. For a long time, the relevant rights were those of citizenship and nationality, which provided a link between public and private international law. More recently, as he reports, supranational human rights have played a greater role. Jayme's position is not uncontested; it is countered in Germany by that of Christian von Bar,

66 See R Michaels, "EU Law as Private International Law? Reconceptualizing the Country-ofOrigin Principle as Wested-rights Theory (2006) 2 Journal of Private International Law 195, 226-7.

67 Mansel, supra n 21, 114, against W Wengler, Internationales Privatrecht, vol 1 (Berlin, de Gruyter, 1983), 23-4.

68 Michaels, supra n 61; similarly Mansel, supra n 21, 114.

69 Mankowski, supra n 59, 258-60.

70 On Kant's importance for private international law, see also K Siehr, "Kant and Private International Law" (2001) 2 European Business Organization Law Review 767. A Kantian reconceptualization of private international law is the theme of F Rödl, "Weltbürgerliches Kollisionsrecht. Über die Form des Kollisionsrechts und ihre Einlösung im Recht der Europäischen Union" (PhD Thesis EUI Florence, 2008).

71 Jayme, supra n 50, 23. More extensively, E Jayme, Menschenrechte und Theorie des Internationalen Privatrechts, in E fayme, Internationale Privatrecht und Völkerrecht (Heidelberg: CF Müller, 2003), 95. Another brief discussion in this volume is that by Mansel, supra n 21, 128-9. 
who argues against human rights as foundation and limit of private international law. ${ }^{72}$

What exactly is the role of human rights in private international law? Part of their role is to provide the basis of a public policy exception against odious foreign law, discussed in the contribution by Andreas Spickhoff. ${ }^{73}$ Spickhoff rightly argues that it would be neither appropriate nor necessary to view the exception itself as originating in international law. ${ }^{74}$ (Whether the situation is different for European public policy is another matter. $)^{75}$ Instead, because human rights are integrated into domestic German law, they play an important role in determining the content of the domestic public policy exception. Of course, this leads to an ambiguous result regarding the relevance of public international law: public international law plays a role only insofar as it represents domestic law, and only as an exception to, and not a foundation of, the ordinary determination and application of the applicable law. ${ }^{76}$

But human rights are not only an exception to the application of "normally" applicable law, they can also become the basis for its determination. Jayme briefly discusses how the European Court of Justice has invoked rules against discrimination in the law of family names. ${ }^{77}$ This could eventually make it necessary to replace nationality as a connecting factor by habitual residence (and would thereby create a late victory for Savigny over Mancini's openly political private international law). An even bigger role for human rights would emerge if party autonomy could be based on them, as the International Law Institute held in a 1991 resolution. ${ }^{78}$ Within the European Union, such ideas have already gained some prominence. ${ }^{79}$

72 G van Bar, "Menschenrechte im Kollisionsrecht" (1994) 33 Berichte der deutschen Gesellschaft für Völkerrecht 191.

73 A Spickhoff, "Der völkerrechtsbezogene ordre public", in Leible and Ruffert, supra n 1, 275.

74 Ibid, 277-81, against G Jaenicke, "Zur Frage des internationalen ordre public" (1967) 7 Berichte der deutschen Gesellschaft für Völkerrecht 77.

75 J Basedow, "Die Verselbständigung des europäischen ordre publique", in M Coester, D Martiny and KA Prinz von Sachsen Gessaphe (eds), Privatrecht in Europa - Vielfalt, Kollision, Kooperation; Festschrift für Hans Jürgen Sonnenberger zum 70. Geburtstag (München, Beck, 2004), 291; for a more critical view, see I Thoma, "Die Europäisierung und die Vergemeinschaftung des nationalen ordre public" (Tübingen, Mohr 2007); see also Spickhoff, supra n 73, 285-6.

76 The latter is true only when one views public policy as an exception. Spickhoff, following Klaus Schurig, establishes public policy as a specific choice-of-law rule. See A Spickhoff, Der ordre public im internationalen Privatrecht, Entwicklung, Struktur, Konkretisierung (Neuwied, Metzner, 1989).

77 Jayme, supra n 50, 25-6, discussing ECJ, 2 Oct 2003, case C-148/02, Garcia Avello [2003] ECR I-11613; see also ECJ, 27 Apr 2006, Case C-96/04, Standesamt Stadt Niebüll ("Grunkin-Paul"), [2006] ECR I-3561; for discussion, Meeusen, supra n 61, 292ss.

78 Jayme, supra n 50, 37-8; see already E Jayme, "L'autonomie de la volonté des parties dans les contrats internationaux entre personnes privées" (1991) 64-I Annuaire de l'Institut de Droit International 14, 63ss; S Leible, "Parteiautonomie im IPR - Allgemeines Anknüpfungsprinzip oder Verlegenheitslösung?", in HP Mansel et al (eds), Festschrift für fayme (München, Sellier 2004), 485.

79 See now V van den Eckhout, "Promoting Human Rights within the Union: The Role of European Private International Law" (2008) 14 European Law fournal 105 
It remains to be seen whether this would be asking too much of human rights. But it is worth noting that this alleged rise in the importance of public international law actually represents a decline in its traditional role as law between states. The abolition of nationality (as defined by states) and the constraints towards state-based limitations on party determination of law reduce the impact of public international law as a law between nations. The rise of human rights as a basis of private international law suggests a rise of the private, at the cost of the public. It is not clear that this concept of human rights is necessarily a public one at all. (The same is true for citizenship. Karen Knop shows how the citizenship concept as used and established within private international law should be viewed as a private form of citizenship. ${ }^{80}$ ) Today, the site of human rights is usually sought in treaties between nations; this is what justifies their character as public international law. But the historical notion of human rights as prior to states suggests they are better placed beyond the distinction of public and private - they are rights against states, but they also permeate private relations (as discussions on the UK Human Rights Act have made quite clear ${ }^{81}$ ). Ironically, the increasing role of human rights in private international law restricts the freedom of states at large, and therefore reduces the role of the international system of states, and of traditional public international law, to private international law. The more private international law focuses on the individual and his rights, the less room remains for relations between states.

\section{International Egonomic Law: A Merger of Public and Private?}

If there is one area in which it may appear obvious that public and private international law must merge, this is the area of economic law. ${ }^{82}$ On the one hand, participants in global markets are subject to rules from both public and private international law, so a full picture of the relevant law would have to address both. On the other hand, states as market participants are increasingly subject to rules of private rather than public international law, so the same merger seems unavoidable. It is one of the most fascinating aspects of this book that it shows up the problems with such a view.

80 Karen Knop, "Public/Private Citizenship" (2008) 71 Law and Contemporary Problems (forthcoming).

81 Campbell v Mirror Group Newspapers Ltd [2004] UKHL 22 (6 May 2004); G Phillipson, "Clarity Postponed? Horizontal Effect after Campbell", in H Fenwick, G Phillipson, R Masterman (eds), Fudicial Reasoning under the UK Human Rights Act (Cambridge University Press, 2007), 143. See more generally, JH Knox, "Horizontal Human Rights Law" (2008) 102 American fournal of International Law 1.

82 AF Lowenfeld, International Economic Law (Oxford University Press, 2002). 


\section{International Economic Law}

In a central essay in this book, Klaus Schurig addresses the question of whether there is methodological convergence or divergence between public and private international law - especially, but not exclusively, in international economic law. ${ }^{83}$ His answer may be surprising to outsiders to the German discourse: ${ }^{84}$ Schurig sees neither convergence nor divergence but complete separation. Public and private international law concern different questions and use different methods. International economic law is for him a conglomerate of very diverse rules - an interesting field of study, but not a discipline. (Unfortunately, the parallel study in this book by a public international lawyer, Albrecht Weber's study on the tension between markets and social welfare as goals of international economic law, does not address this question and instead focuses only on public international law. ${ }^{85}$ )

Schurig's view (which is not unanimously shared in Germany) must be understood against a German background. Since the beginning of the last century, the concepts of "economic law" and "international economic law" have often been used to challenge the traditional German distinction between private and public law and replace it with a functional differentiation of different legal systems. ${ }^{86}$ By denying a separate sphere of private law, such attempts have usually been coupled with a stronger emphasis on the regulatory aspects of law. Such an understanding of law is very much in a accordance with US thinking about the law, ${ }^{87}$ but does not chime so well, as Schurig makes clear, with traditional German systematic thinking. ${ }^{88}$ Public international lawyers may be happy to treat private international law as an annex to their own discipline. From a private international law perspective, this does not do justice to the specific character of choice-of-law rules.

As a former student of Schurig, I may be considered biased in his favour. But it appears that a view that keeps private and public international law apart, for analytical purposes, holds huge advantages. Only a separation enables us to recognise the technical and methodological differences between private and public international law. If indeed public and private international law work as functional equivalents, this is all the more reason to keep them apart in the analysis to get a clearer understanding of how exactly the law deals with specific problems, how public relates to private within the combined regulation.

83 Schurig, supra n 15.

84 See, eg, JP Trachtman, "The International Economic Law Revolution” (1996) 17 University of Pennsylvania Fournal of International Economic Law 33, 40 ("The Disappearance of Private International Law").

85 A Weber, "Marktfreiheit oder kooperative Gemeinwohlverwirklichung im internationalen Wirtschaftsrecht?", in Leible and Ruffert, supra n 1, 71, 72-3.

86 F Kübler, "Wirtschaftsrecht in der Bundesrepublik. Versuch einer wissenschaftlichen Bestandsaufnahme", in D Simon (ed), Rechtswissenschaft in der Bonner Republik (Frankfurt, Suhrkamp, 1994), 364.

87 See Jansen and Michaels, supra n 7, 352-3.

88 Schurig, supra n 15, 56-7. 
The attack on the distinction tends to confuse analytical separation with substantive results, assuming that such a distinction by necessity implies a stronger position for the private. This assumption is unwarranted, as can be observed in another contribution to the book. Eberhard Eichenhofer asks whether social standards that are based in public international law can be protected better through private international law or through (public) unified law. ${ }^{89}$ The question makes it clear that the tension between individual and common interests is not the same as that between private and public international law: private international law may well protect common interests (or at least the interests of the weaker party); public international law may be used to protect individual interests. Unfortunately, Eichenhofer appears to assume that private international law would be denatured if the designation of the applicable law is based on protective interests instead of the closest connection. Under such a view, his result - unified law is superior - is almost unavoidable. But modern private international law has long acknowledged protection of weaker parties as a legitimate goal, even within a Savignyan paradigm.

In addition, specific methods of conflict of laws have been developed for social security law, as discussed briefly by Eichenhofer, ${ }^{90}$ and more generally for administrative law, discussed in this book by Christoph Ohler. ${ }^{91}$ Ohler argues that conflicts rules for administrative law (including the possibility of applying foreign law) are necessarily different from those for private law (though they can derive inspiration from the latter). His view that foreign public law poses special problems is of course not confined to Germany, ${ }^{92}$ nor is it incorrect as such. However, it seems that the essential difference between private international law and international administrative law is overrated (just as, some 100 years ago, the desire in Germany to establish substantive administrative law as essentially different from substantive private law was not upheld for long). Ohler postulates two relevant differences between both: first, private international law presumes equivalence of legal orders (while international administrative law does not); second, private international law assumes conflicts (while international administrative law frequently acts in situations with no conflicts). Both differences seem exaggerated - equivalence of legal orders in the abstract way in which it underlies private international law is a postulate also of public international law;

89 E Eichenhofer, "Sicherung völkerrechtlich konsentierter sozialer Mindeststandards durch Kollisions- oder Einheitsrecht?", in Leible and Ruffert, supra n 1, 215.

90 Ibid at 224; in more detail, see E Eichenhofer, Internationales Sozialrecht und Internationales Privatrecht (Munich, Beck, 1987).

91 C Ohler, "Internationales Verwaltungsrecht - ein Kollisionsrecht eigener Art?", in Leible and Ruffert, supra n 1, 131; see also C Ohler, Die Kollisionsordnung des Allgemeinen Verwaltungsrechts (Tübingen, Mohr/Siebeck 2005). The classic German study is K Neumeyer, Internationales Verwaltungsrecht, 4 vols (Munich \& Berlin, J Schweitzer, 1910-36).

92 PJ McConnaughy, "Reviving the 'Public Law Taboo' in International Conflict of Laws" (1999) 35 Stanford Fournal of International Law 255; WS Dodge, "Breaking the Public Law Taboo" (2002) 43 Harvard International Law Fournal 161. 
conflicts are no more defining of private international law than of other disciplines. This is not meant to minimise the differences that remain. But it seems that a system of conflicts rules for administrative law is more similar to a conflicts system for private law rules than it is similar to public international law. In this sense, the development of conflicts rules for areas outside of private law as a field signifies a rise of private international law as a method.

\section{The State in the Economy}

The distinction between public and private international law becomes especially problematic where the state is involved as an actor in economic transactions. While those transactions are structurally similar to those among private actors, the state is at the same time protected and constrained by its role as a sovereign subject.

Public international law accounts for this situation by confining certain doctrines to situations where the state acts as a sovereign. Oliver Dörr analyses one such doctrine, state immunity. ${ }^{93}$ After discussing the doctrine in public international law, he finds that private international law, especially the law of recognition and enforcement of foreign judgments, can accommodate immunity - either within a public policy exception, or, between EU Member States, through limitations in the scope of application of the Brussels Regulation. This much should be uncontroversial. The European Convention on State Immunity goes even further and excludes, in its Article 23, all enforcement except where the defendant state has consented to it. But the impression that state immunity will usually trump private international law is in tension with the tendency, described by Dörr, towards restricting state immunity - for commercial acts, ${ }^{94}$ for liability for torture ${ }^{95}$ - and thereby reopening issues of private international law. When the US Supreme Court decided, in its Altmann decision, that Austria could not claim immunity against a claim to return five Klimt paintings expropriated during the Nazi era to the descendants of the owner, state immunity was only the first issue. ${ }^{96}$ The court did not touch on a number of difficult questions regarding the applicable law, including the problem of whether defendant states should be allowed to rely on their own rules of law in defending claims. ${ }^{97}$

93 O Dörr, "Staatenimmunität als Anerkennungs- und Vollstreckungshindernis", in Leible and Ruffert, supra n 1, 175.

94 See eg Kuwaiti Airways Corporation v Iraqi Airways Co., [1995] 1 WLR 1147.

95 See only fones v Saudi Arabia, [2006] UKHL 26. The relationship between sovereign immunity and the duty to provide redress for victims of torture is currently the subject of hot debate. See only, most recently, "Symposium: State Immunity in Civil Proceedings for Serious Violations of Human Rights" (2007) 18 European Fournal of International Law 903-70; E Bates, "State Immunity for Torture" (2007) 7 Human Rights Law Review 651.

96 Altmann v Republic of Austria, 541 US 677 (US S Ct 2004).

97 The case was decided by arbitration, and the parties agreed that Austrian law should govern. The arbitral award that ensued is available at http://www.adele.at/Schiedsspruch/schiedsspruch. html. 
Choice-of-law issues must likewise result where redress is granted to torture victims, since international law treaties do not themselves provide the necessary details of such claims.

Problems of private international law are also lurking in the background of the topic of sovereign state insolvency, discussed by Christian Tietje in this book as problems involving public and private international law. ${ }^{98}$ Cases before German courts involving Argentina show this mixture clearly. When Argentina defaulted on its debts, it had waived its sovereign immunity and acceded to the application of German law and the exclusive jurisdiction of courts in Frankfurt. The cases that arose looked very much like ordinary private law cases in many ways. The main remaining question - whether Argentina could invoke its own moratorium and its financial situation against the claim - creates problems for private and public international law. From a private international law perspective, the question was whether the Argentinian moratorium rules should become applicable as "internationally mandatory rules". From a public international law perspective, the question was whether Argentina could rely on a state of necessity, perhaps based on Article 25 of the Draft Articles on State Responsibility for Wrongful Acts. Both alternatives are unsatisfactory, because they would not enable debt restructuring as the most promising solution.

Tietje argues that issues like that of sovereign debt necessarily combine public and private international law, and that insufficient attention has been paid to arbitral awards in the area. ${ }^{99}$ However the solution he sees as most promising is one of pure private international law: collective action clauses, terms in the lending contracts in which creditors and debtor states agree on restructuring procedures. This is a complex attempt to recreate, entirely on the basis of individual contracts, an insolvency procedure like that provided, domestically, by states. The result is a situation that can be mastered entirely through private international law: the respective contracts will be enforceable, and state interests and state necessity are no longer relevant criteria in the analysis. Whether this is desirable or not, in essence it looks like a clear victory of private over public international law, and of private over public ordering.

G Tietje, "Staateninsolvenz und Kapitalaufnahme auf internationalen Anleihemärkten", in Leible and Ruffert, supra n 1, 193. Much has been written on these issues. For a perspective from a German private international law scholar, see T Pfeiffer, "Zahlungskrisen ausländischer Staaten im deutschen und internationalen Rechtsverkehr" (2003) 102 Zeitschrift fir vergleichende Rechtswissenschaft 141.

99 Ibid, 204-8. For a recent critique of arbitration in the area of sovereign bonds, see M Waibel, "Opening Pandora's Box: Sovereign Bonds in International Arbitration" (2007) 101 American Fournal of International Law 711. For the usefulness of conflict-of-laws analysis, see AJ Borklund, "Private Rights and Public International Law: Why Competition among International Economic Law Tribunals is not Working" (2007) 59 Hastings Law Fournal 241. 


\section{E. The Return of the Private}

This overview of themes and perspectives may be partial and unrepresentative. Nonetheless, it should suffice to put into doubt the thesis that public international law is gaining ground over private international law. State interests in public international law are becoming unimportant: general public international law places hardly any constraints on private international law, comity as a basis of private international law is no longer a public international law concept, and treaties as a traditional means of choice-of-law unification are giving ground to restatement approaches. Trade law has an impact, but its focus is on protecting private actors' right of access to markets, not state interests. Indeed, if individual interests - human rights, citizenship - have a growing impact, it is doubtful whether they are truly public concepts. International economic law is turning towards private agreements and private international law, not public international law.

These developments suggest not only a shift in the hierarchy between the individual and the state - a shift that public international law has long acknowledged and accommodated. They suggest also a shift away from the balancing of interests that is typical of public international law towards the technical character of private international law. The restructuring of sovereign debt is perhaps the clearest example for this development. General invocations of sovereignty and of political interests with no clear definition are giving ground to exact and rigid rules. In this sense, the thesis that public and private international law are necessarily merging is not substantiated. Instead, private international law is expanding its scope.

Private international law cannot remain unchanged in this process. If it is supposed to master many more tasks than those assigned to it by Savigny, whose thinking still permeates German discussions on private international law, it will have to learn from public international law, if only because many of its new tasks were formerly those of public international law. Many contributions in this book show that such learning processes are going on. In the end, this learning experience may present the biggest influence of public on private international law. That such a learning experience can be had from the book before us is its great achievement. 